Ann. Biol. anim. Bioch. Biophys., 1979, 19 (1A), 103-109.

\title{
Preliminary characterization of calcium binding to melano- somes isolated from amphibian oocytes
}

\author{
by Annie CARTAUD, R. OZON \\ Laboratoire de Physiologie de la Reproduction et ERA, CNRS 694, \\ Université P.-et-M. Curie, 9, quai Saint-Bernard, 75005 Paris, France.
}

Summary. Calcium binding to isolated melanosomes from Xenopus laevis and Rana esculenta oocytes has been assessed by equilibrium dialysis and centrifugation techniques. Calcium binding was a concentration-dependent saturable process, revealing two distinct types of binding sites. In Xenopus dissociation constant and maximum binding capacity were $21 \mu \mathrm{M}$ and $0.18 \mathrm{nmole} / \mathrm{oocyte}$ for the high affinity sites; $\mathrm{HCl}$ treatment destroyed the high affinity binding sites. $\mathrm{MgCl}_{2}$ or $\mathrm{MnCl}_{2}(2 \mathrm{mM})$ inhibited calcium binding to melanosomes, whereas procaine had no effect. Lanthanum $(\geqslant 0.1 \mathrm{mM})$ was also found to be an inhibitor of high affinity sites.

\section{Introduction.}

The cytosol concentration of free $\mathrm{Ca}^{2+}$ in most eukariotic cells ranges from $10^{-6}$ to $10^{-8} \mathrm{M}$. Changes in free $\mathrm{Ca}^{2+}$ concentration have been proposed as critical modulators of numerous intracellular physiological and biochemical processes ; Rasmussen ef al. (1975) have suggested that $\mathrm{Ca}^{2+}$ could be an important messenger for the mediation of hormone action.

The steroid hormone, progesterone, induces meiotic maturatilon of the fullgrown amphibian oocyte (Smith, 1975). Recent studies have indicated that $\mathrm{Ca}^{2+}$ movements might be involved in the initiation of Xenopus oocyte maturation (Wasserman and Masui, 1975 ; Marot ef al., 1976 ; Schorderet-Slatkine et al., 1976 ; Moreau et al., 1976 ; O'Connor ef al., 1977). Evaluation of cellular $\mathrm{Ca}^{2+}$ metabolism is difficult because intracellular $\mathrm{Ca}^{2+}$ is highly compartimentalized. However, experiments in which the photoluminescent protein, aequorin, was injected into Xenopus oocytes have shown that free $\mathrm{Ca}^{2+}$ wass less than $10^{-7} \mathrm{M}$ and also that the mechanisms regulating its concentration were very efficient (Bellé ef al., 1977). The Xenopus oocyte must therefore contain fast $\mathrm{Ca}^{2+}$ sequestering equipment. An experimental approach to studying $\mathrm{Ca}^{2+}$ metabolism has involved the use of subcellular fractions ; $\mathrm{Ca}^{2+}$ interactions with subcellular fractions have shown that mitochondria (Carafoli, 1974) plasma membranes (Mc Donald ef al., 1976) and microsomes (Meissner ef al., 1973) could act as important regulators of intracellular calcium distribution. In the present 
communication we demonstrate that calcium binding to isolated melanosomes from Xenopus laevis and Rana esculenta oocytes is a concentration dependent saturable process ; our results, further suggest that melanosomes could act as important regulators of intracellular $\mathrm{Ca}^{2+}$ in melanin containing cells.

\section{Material and methods.}

Animals. - Xenopus laevis from South Africa (de Rover, Holland) and Rana esculenta from Couetard (France) were bred and maintained under laboratory conditions.

Chemicals. - Chemicals were obtained from following sources: ${ }^{45} \mathrm{CaCl}_{2}$ (approximately $1 \mathrm{mCi} / 1,2 \mu \mathrm{mol}$ ) from CEA (France) ; collagenase $(200 \mathrm{U} / \mathrm{mg}$ ) from Worthington Biochemical Co ; procaine from Sigma Chemical Co, St Louiss, MO. (USA); pronase B grade from Calbiochem; lanthanum chloride from Prolabo, Rhône-Poulenc (France). Equilibrium dialysis was performed using standard cellulose dialysis membranes $(6 \mathrm{~mm}$ in diameter) from $\mathrm{A}$. H. Thomas Co, Philadelphia, PA. (USA).

\section{Oocytes preparation.}

Experiments with isolated oocytes. - Specimens of Xenopus laevis were anesthetized with MS $222(1 \mathrm{~g} / \mathrm{l})$ (Sandoz) Pieces of ovary were removed and the oocytes defolliculated by enzymatic treatment with collagenase (Schorderet-Slatkine and Drury, 1973). They were then equilibrated in Merriam's solution (Merriam, 1971) ; fullgrown oocytes ( $\geqslant 1.2 \mathrm{~mm}$ diameter) were selected under stereoscopic microscope.

Cell fractionation. - Isolated oocytes or ovarian tissue were homogenized in medium A ( $5 \mathrm{ml} / \mathrm{g}$ of tissue) containing sucrose $0.25 \mathrm{M}$, Tris- $\mathrm{HCl} 0.05 \mathrm{M}, \mathrm{KCl} 75 \mathrm{mM}$, $\mathrm{pH} 7.4$ with a Potter Elvehjem homogenizer. After filtration the homogenate was centrifuged at $2000 \mathrm{~g}$ for $15 \mathrm{~min}$. After resuspension in medium B (sucrose $2 \mathrm{M}$; tris- $\mathrm{HCl} 0.05 \mathrm{M}$ and $\mathrm{KCl} 75 \mathrm{mM}$; potassium citrate $0.3 \mathrm{M}, \mathrm{pH} 7.4$ ), the resulting pellet was centrifuged for $60 \mathrm{~min}$. at $100,000 \mathrm{~g}$ (rotor SW-50.1). Three main fractions were obtained :

I. A black pellet corresponding to the "melanosome » fraction ;

II. A solid brown cap at the top of the fube representing the " membrane " fraction ;

III. A vitellus fraction befween I and II.

The melanosome fraction was washed 3 times in medium $B$ to remove all traces of vitellogenin, and then tested for calcium binding after resuspension in medium $\mathrm{C}$ (Tris- $\mathrm{HCl} 0.05 \mathrm{M} ; \mathrm{KCl} 75 \mathrm{mM}, \mathrm{pH} 7.4$ ). Before testing the vitellus fraction, the sucrose $2 \mathrm{M}$ and the potassium citrate were removed by dialysis against deionized water for 24 hrs. The $2000 \mathrm{~g}$ supernatant was centrifuged for $60 \mathrm{~min}$. at $100,000 \mathrm{~g}$; the cytosol corresponds to the $100,000 \mathrm{~g}$ supernatant and the pellet to the " microsomal and mitochondrial $»$ fraction used to test calcium binding after washing in medium $A$ and resuspension in medium $C$. 
Calcium-binding assay be equilibrium dialysis. - Dialysis membranes had been previously treated with $2 \mathrm{mM}$ EDTA solution, followed by extensive washing with deionized water or standard buffer (medium C). After adding $1 \mathrm{ml}$ of different fractions in medium $C$ the dialysis bag was placed in an Erlenmeyer flask containing $100 \mathrm{ml}$ of standard buffer in the presence of $1.0 \mu \mathrm{M}$ to $1 \mathrm{mM}$ of $\mathrm{CaCl}_{2}$ and $0.8 \mu \mathrm{Ci}$ of ${ }^{45} \mathrm{CaCl}_{2}$. Dialysis was performed at $4{ }^{\circ} \mathrm{C}$ with stirring. Equilibrium was reached in $24 \mathrm{hrs}$. The ${ }^{45} \mathrm{Ca}^{2+}$ content in each compartment was determined by the use of a liquid scintillator counter.

Melanosome calcium binding assay by centrifugation. -70 to $100 \mu \mathrm{g}$ of melanosomal proteins suspended in $1 \mathrm{ml}$ of medium $C$ were incubated in $1 \mathrm{ml}$ of standard buffer in presence of $1.0 \mu \mathrm{M} 1 \mathrm{mM} \mathrm{CaCl}_{2}$ and $0.1 \mu \mathrm{Ci}$ of ${ }^{45} \mathrm{CaCl}_{2}$. After the melanosome fraction was added, the suspension was incubated for $10 \mathrm{~min}$. and centrifuged at $8500 \mathrm{~g}$ for $10 \mathrm{~min}$. Supernatant radioactivity was assessed using a liquid scintillator counter.

Melanosome $\mathrm{HCl}$ hydrolysis. - Hydrolysis of the melanosome weighed sample $(1 \mathrm{mg} / \mathrm{ml})$ was carried out in $6 \mathrm{~N} \mathrm{HCl}$ at $110^{\circ} \mathrm{C}$ for $48 \mathrm{hrs}$. in evacuated sealed tubes. After hydrolysis, the contents were centrifuged and the pellet was washed and assayed for calcium binding.

Radioactivity counting. - Radioactivity was assayed by liquid scintillation spectrometry using $10 \mathrm{ml}$ of a mixture containing PPO $(5,5 \mathrm{~g})$ POPOP $(100 \mathrm{mg})$ in Triton $X$ $100(333 \mathrm{ml})$ and toluene $(667 \mathrm{ml})$. Counting was carried out in a Packard Tri-carb spectrometer model 3320.

Protein assay. - Protein concentration was determined by the method of Lowry ef al. (1951) Before the addition of Folin reagent, the proteins from the melanosome fraction were extracted with 2 p. 100 sodium dodecylsulfate at $100^{\circ} \mathrm{C}$ for $2 \mathrm{~min}$. (Marot et al., 1977) and the melanin removed by centrifugation.

\section{Results.}

Calcium binding in subcellular fractions.

After removal of follicular cells, oocytes were homogenized and fractionated (Material and methods) ; the main fractions were assessed for total calcium binding by equilibrium dialysis (fig. 1). All fractions bound $\mathrm{Ca}^{2+}$; when saturable binding was studied high non saturable binding was found in the vitellus fraction. In the four other fractions saturable binding was observed. The melanosome fraction bound $\mathrm{Ca}^{2+}$ specifically with the highest binding capacity. This fraction was further analyzed, and we present here a preliminary characterization of calcium binding to purified melanosomes.

\section{Characteristics of calcium binding to melanosomes.}

Calcium binding to isolated melanosomes is a concentration dependent saturable process. Scatchard analysis of a typical binding study assayed by equilibrium dialysis is shown in figure 2. Two types of binding sites were determined. The mean $K_{D}$ values obtained from a total of five determinations at $4^{\circ} \mathrm{C}$ were $21 \pm 5 \mu \mathrm{M}$ in Xenopus 
laevis and $42 \pm 13 \mu \mathrm{M}$ in Rana esculenta. In Xenopus binding capacity was $0.18 \mathrm{nmol}$ per oocyte. No significant amount of endogenous $\mathrm{Ca}^{2+}$ appeared to remain bound to high affinity sites after isolation of the melanosomes; melanosomes isolated in the presence of EGTA or EDTA bound $\mathrm{Ca}^{2+}$ (after removal of the complexing reagents by dialysis) with a similar $K_{D}$ as those reported without EDTA or EGTA in the isolation medium. This indicates that high affinity sites are entirely eluted during melanosome isolation.
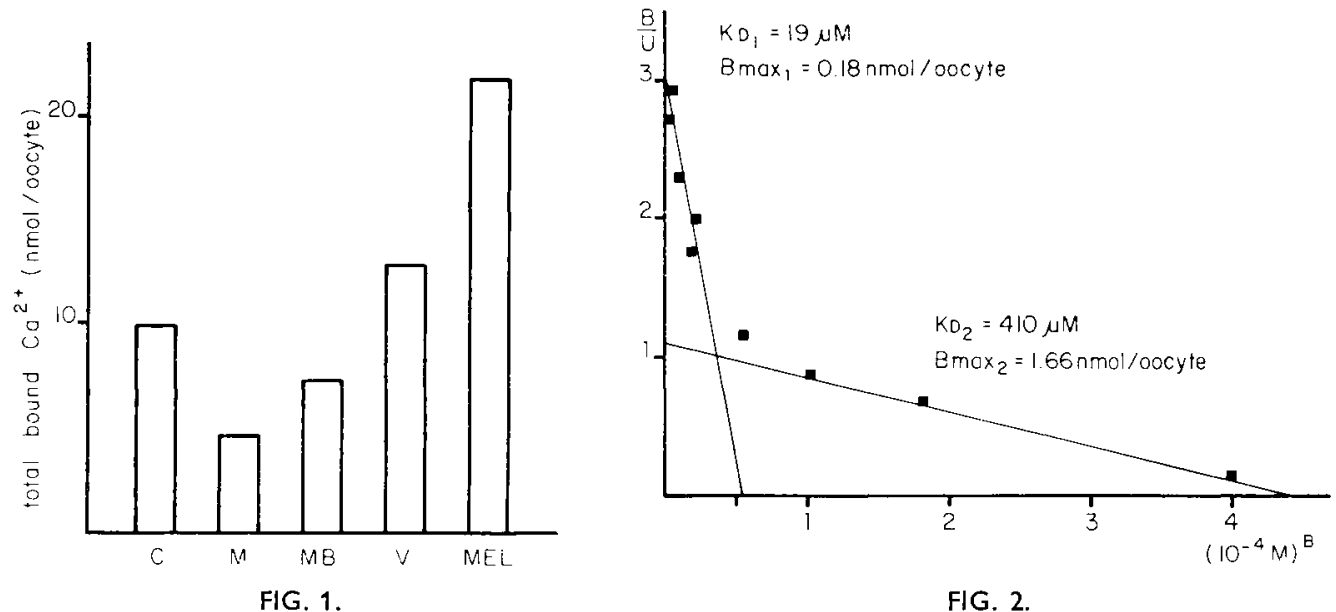

FIG. 2 .

FIG. 1. - Total bound calcium in subcellular fractions. Calcium binding was determined by equilibrium in cytosol (C), mitochondrial and microsomal fraction $(M)$, membranes $(M B)$, vitellus $(V)$ and melanosomal fraction (MEL) from Xenopus oocytes, prepared as described in materials and methods. Equivalent of 330 oocytes per $\mathrm{ml}$ were dialysed against $100 \mathrm{ml}$ of medium $\mathrm{C}$ in presence of $10^{-6} \mathrm{M}$ of $\mathrm{CaCl}_{2}$ and $0,8 \mu \mathrm{Ci}$ of ${ }^{45} \mathrm{CaCl}_{2}$ for $24 \mathrm{hrs}$.

FIG. 2. - Calcium binding to melanosomes. Melanosomes were prepared as described in materials and methods. Binding was assayed by equilibrium dialysis. Protein concentration was $100 \mu \mathrm{g}$ of protein per $\mathrm{ml}$. Scatchard plot (Scatchard, 1949) : $\mathrm{B}=$ bound $\mathrm{Ca}^{2+} ; \mathrm{U}=$ free $\mathrm{Ca}^{2+} ; \mathrm{K}_{\mathrm{D}}=$ dissociation constant ; $\mathrm{B}$ max $=$ maximum binding capacity.

Dialysis and centrifugation technique yield similar affinity constants. The centrifugation technique was used in subsequent studies since it was easier and more rapid.

As measured by centrifugation, calcium binding to melanosomes reached a steady state in $10 \mathrm{~min}$. at all calcium concentrations studied.

The calcium binding was linear between 10 and $200 \mu \mathrm{g}$ of melanosomal proteins in each sample. Above $200 \mu \mathrm{g}$ the binding became non-linear. All binding assays contained between 50 to $100 \mu \mathrm{g}$ of proteins.

In order to know if $\mathrm{Ca}^{2+}$ bound to melanoproteins or to the melanin polymer, proteins were removed by $6 \mathrm{NHCl}$ hydrolysis. Calcium binding to the meianin was assessed by equilibrium dialysis, but high affinity binding was never detected, indicating that binding sites were either removed by the $\mathrm{HCl}$ treatment or were destroyed. Treatment of melanosomes with pronase $(0,3 \mathrm{mg} / \mathrm{ml})$ for $12 \mathrm{hrs}$ at $4^{\circ} \mathrm{C}$ slightly increased calcium binding to melanosomes. 
All standard assays were performed at $\mathrm{pH} 7.4$; calcium binding steadily increased from $\mathrm{pH} 6.0$ to $\mathrm{pH} 9.0$ (fig. 3).

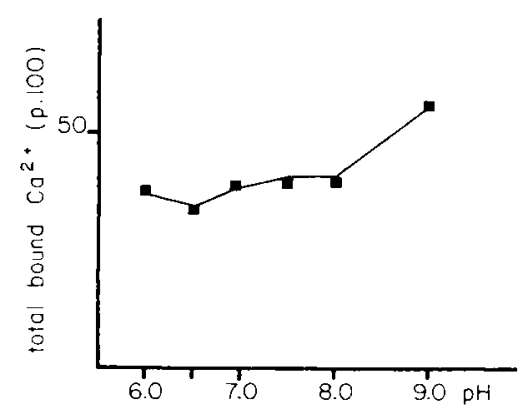

FIG. 3 .

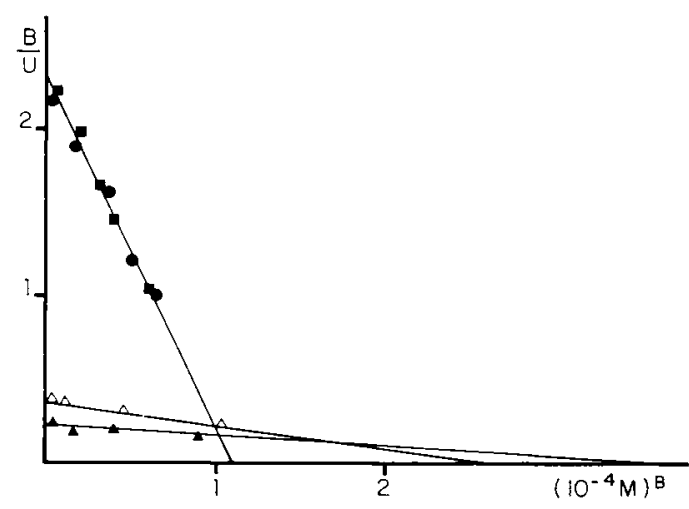

FIG. 4.

FIG 3. - Effect of $\mathrm{pH}$ on calcium binding to melanosomes. Centrifugation assays were performed in the presence of $20 \mu \mathrm{M}$ of $\mathrm{CaCl}_{2}$, as described in materials and methods. Binding is expressed as the percentage of bound calcium/total calcium in the medium.

FIG. 4. - Effect of lanthonum chloride on calcium binding to melanosomes. Calcium binding was assayed by equilibrium dialysis in the presence of various amounts of $\mathrm{Ca}^{2+}(1 \mu \mathrm{M}$ to $1 \mathrm{mM})$ an of three $\mathrm{La}^{3+}$ concentrations: $10^{-6} \mathrm{M}\left(--10^{-4} \mathrm{M}(\Delta-\Delta)\right.$ and $10^{-2} \mathrm{M}(\Delta-\Delta)$. Control without La $\mathrm{a}^{3+}$ $(\mathrm{O}-\mathrm{o})$. Protein concentration was $50 \mu \mathrm{g}$ per $\mathrm{ml}$. Scatchard plot $(15): \mathrm{B}=$ bound $\mathrm{Ca}^{2+} ; \mathrm{U}=$ free $\mathrm{Ca}^{2+}$.

\section{Effect of different ions and procaine.}

When $\mathrm{KCl}$ concentration was less than $100 \mathrm{mM}$, calcium binding was unmodified. Above that concentration, binding was inhibited; 50 p. 100 of the original binding level was reached at $2 \mathrm{M} \mathrm{KCl}$.

$\mathrm{Ca}^{2+}$ binding in the presence of $2 \mathrm{mM} \mathrm{Mn}^{2+}$ was tested; both divalent cations inhibited calcium binding. About 50 p. 100 inhibition was achieved at $2 \mathrm{mM}$ of $\mathrm{Mn}^{2+}$ of $\mathrm{Mg}^{2+}$.

Lanthanum was also found to be an inhibitor of calcium binding (fig. 4). A La La $^{3+}$ concentration of $0.1 \mathrm{mM}$ totally inhibited calcium binding to melanosomes.

Procaine $0.5 \mathrm{mM}$ to $5 \mathrm{mM}$ did not inhibit calcium binding to melanosomes.

\section{Discussion.}

The binding of calcium to melanosomes is a saturable process which exhibits two distinct types of binding sites. The high affinity dissociation constant $K_{D}$ was found to be about $20 \mu \mathrm{M}$ in both Xenopus and Rana. This value is comparable with those reported for $\mathrm{Ca}^{2+}$ binding to plasma membranes, microsomes or to numerous calcium binding proteins (Mc Donald ef al., 1976 ; Kretsinger, 1976).

Melanosomes are complex subcellular organelles surrounded by a membrane composed of insoluble melanin polymer and firmly bound proteins in unequal pro- 
portions. A preliminary characterization of amphibian melanoproteins was achieved after SDS extraction (Marot et al., 1977), at least twenty proteins were resolved by polyacrylamide gel electrophoresis. In order to know the localisation of $\mathrm{Ca}^{2+}$ binding sites, melanoproteins were extracied by SDS (dara not given), and it was found that the binding sites were not extracted in these conditions. As reported by Marot ef al. (1977), only $\mathrm{HCl}(6 \mathrm{~N})$ hydrolysis for $20 \mathrm{hrs}$. removes all melanosomal proteins and abolishes $\mathrm{Ca}^{2+}$ binding to melanin. It was reported that synthetic melanin only binds $\mathrm{Ca}^{2+}$ very slightly (Potts and $\mathrm{Au}, 1976$ ). This suggests $\mathrm{Ca}^{2+}$ binding at the melanoprotein level and, to our knowledge, it is the first report attributing a biochemical function to melano-proteins.

The finding that $\mathrm{Mg}^{2+}$ and $\mathrm{Mn}^{2+}$ at high concentration ( $2 \mathrm{mM}$ ) inhibit $\mathrm{Ca}^{2+}$ binding to melanosomes is of interest; it was demonstrated that the ionophore A 23187 in the presence of $\mathrm{Mg}^{2+}(10 \mathrm{mM})$ (Wasserman and Masui, 1975) or $\mathrm{Mn}^{2+}$ (10 mM) (unpublished results) triggered Xenopus oocyte maturation in the absence of hormonal stimulation. These divalent cations could induce a $\mathrm{Ca}^{2+}$ release by inhibiting calcium binding to melanosomes. However, the conclusions are ambigous regarding the biological significance of $\mathrm{Ca}^{2+}$ binding to oocyte melanosomes, particularly during hormonally induced maturation.

Total calcium concentration in the whole oocyte ranges from 1 to $10 \mathrm{mM}$; $\mathrm{Ca}^{2+}$ binding capacity of melanosomes at high affinity sites represents between 2 to $20 \mathrm{p}$. 100 of total $\mathrm{Ca}^{2+}$. Recent experiments using microprobe analysis (unpublished results) confirm that melanosome $\mathrm{Ca}^{2+}$ content is high. It is suggested that melanosomes may play a role in the regulation of calcium metabolism in amphibian oocytes.

Reçu en juillet 1978.

Accepté en septembre 1978.

Acknowledgement. - This work was supported by the Délégation Générale à la Recherche Scientifique et Technique (Biologie de la Reproduction et du Développement), Contract No 76-7-0711.

Résumé. La fraction des mélanosomes a été isolée par ultracentrifugation à partir des ovocytes de Xenopus laevis et de Rana esculenta. La fixation du $\mathrm{Ca}^{2+}$ sur les mélanosomes a été étudiée par dialyse à l'équilibre et par centrifugation. La liaison du $\mathrm{Ca}^{2+}$ aux mélanosomes est un phénomène saturable. Chez le Xénope, la constante de dissociation est de $21 \mu \mathrm{M}$; la capacité maximum de liaison pour les sites de haute affinité est de 0,18 nmole/ ovocyle. Les sites de haute affinité pour le $\mathrm{Ca}^{2+}$ sont détruits après traitement par $\mathrm{HCl}$ (6 N). $\mathrm{MgCl}_{2}$ ou $\mathrm{MnCl}_{2}$ à la concentration de $2 \mathrm{mM}$ inhibe la fixation du $\mathrm{Ca}^{2+}$ tandis que la procaïne n'a pas d'effet sur la liaison du $\mathrm{Ca}^{2+}$ aux mélanosomes. Le lanthane à une concentration $\geqslant 0,1 \mathrm{mM}$ est un inhibiteur des sites de haute affinité.

\section{References}

BELLÉ R., OZON R., STINNAKRE J., 1977. Free calcium in full grown Xenopus loevis oocyte following treatment with ionophore A 23187 or progesterone. Molec. cell. Endocrinol., 8, 65-72.

CARAFOLI A., 1974. Calcium and cell regulation. Biochem. Soc. Symp., 39, 89-109.

KRETSINGER R. H., 1976. Calcium-binding porteins. Annu. Rev. Biochem., 45, 239-266. 
LOWRY O. H., ROSEBROUGH W. J., FARRA L., RANDALL R. J., 1951. Protein measurement with the Folin phenolreagent. J. Biol. Chem., 193, 265-275.

MC DONALD J. M., BRUNS D. E., JARRET L., 1976. Characterization of calcium-binding to adipocyte plasma membranes. J. biol. Chem., 251, 5345-5351.

MAROT J., BELLÉ R., OZON R., 1976. Recherches sur la maturation de l'ovocyte de Xenopus laevis. Arguments en faveur du rôle des ions calcium. C. R. Acad. Sci. Paris, Ser. D, 282, 1301. 1304.

MAROT J., BELLÉ R., OZON R., 1977. Preliminary characterization of Amphibian melanoproteins. Life Sci., 20, 179-186.

MEISSNER G., CONNER G. E., FLEISCHER S., 1973. Isolation of sarcoplasmic reticulum by zonal centrifugation and purification of $\mathrm{Ca}^{2+}$ pump and $\mathrm{Ca}^{2+}$ binding proteins. Biochim. biophys. Acfo, 298, 246-249.

MERRIAM R. W., 1971. Progesterone-induced maturational events in oocytes of Xenopus laevis. I. Continuous necessity for diffusible calcium and magnesium. Exp. Cell Res., 68, 75-80.

MOREAU M., DORÉE M., GUERRIER P., 1976. Electrophoretic introduction of calcium ions into the cortex of Xenopus laevis oocytes triggers meiosis reinitiation. J. exp. Zool., 197, 443-449.

O'CONNOR C. M., ROBINSON K. R., SMITH L. D., 1977. Calcium, potassium and sodium exchange by full-grown and maturing Xenopus laevis oocytes. Develop. Biol., 61, 28-40.

POTTS A. M., AU P. C., 1976. The affinity of melanin for inorganic ions. Exp. Eye Res., 22, $487-493$.

RASMUSSEN M., JENSEN P., LAKE W., FRIEDMANN N., GOODMAN D. B. P., 1975. Cyclic nucleotides and cellular calcium metabolism 5, 375-394. In G. I. DRUMMOND, P. GREENGARD, G. A. ROBINSON. Advances in cyclic nucleotide research. Raven Press, New York.

SCATCHARD G., 1949. The attraction of proteins for small molecules and ions. Ann. N. Y. Acad. SCI., 51, 660-672.

SCHORDERET-SLATKINE S., DRURY K. C., 1973. Progesterone-induced maturation in oocytes of Xenopus laevis. Appearance of a maturation promoting factor in enucleated oocytes. Cell. Diff., 2, 247-254.

SCHORDERET-SLATKINE S., SCHORDERET M., BAULIEU E. E., 1976. Initiation of meiotic maturation in Xenopus laevis by lanthanum. Nature, 262, 289-280.

SMITH L. D., 1975. Molecular events during oocyte maturation. In WEBER R., The biochemestry of animal development vol. 3, 1-46, Acad. Press.

WASSERMAN W. J., MASUI Y., 1975. Initiation of meiotic maturation in Xenopus laevis oocyte by the combination of divalent cations and ionophore A 23187. J. exp. Zool., 193, 369-375. 